\title{
Latin Syntax in Fifty Years of Generative Grammar
}

\author{
Jaume Mateu \\ Universitat Autònoma de Barcelona \\ jaume.mateu@uab.cat \\ Renato Oniga \\ Università degli Studi di Udine \\ renato.oniga@uniud.it
}

Fifty years have passed since the first attempt to apply generative grammar methods to Latin syntax. The well-known book by Robin Tolmach Lakoff, published in 1968 by the MIT Press with the title of Abstract Syntax and Latin Complementation, was presented as a dissertation in linguistics at Harvard University in 1967, with the title of Studies in the Transformational Grammar of Latin. The Complement System. ${ }^{1}$ In order to celebrate its fiftieth anniversary, we thought it was appropriate to publish a collection of papers written by some distinguished specialists who approach the study of Latin syntax from a generative perspective. Their works show the important research that is being currently carried out in this active field.

In this introduction, we would like to briefly trace the development of this research area, trying to emphasize elements of continuity, changes, results, and problems. Although generative grammar has provided very important contributions to phonology and morphology as well, it is nonetheless clear that, from the very beginning, its theoretical focus has been on syntax. ${ }^{2}$

\section{The generative research project}

The development of generative studies on Latin language has been conditioned by the internal evolution of the syntactic theory in general linguistics. As is well known, in the history of generative grammar we can identify different stages, which schematically bring us back to the success of some of the main books published by Noam Chomsky. The beginning can be traced back to the first transformational phase, from Syntactic Structures (Chomsky 1957) to the so-called "Standard Theory" of Aspects of the Theory of Syntax (Chomsky 1965). A second phase goes from the "Extended Standard Theory" (Chomsky 1973) to Lectures on Government and Binding (Chomsky 1981). In the end, as a continuation of the so-

1. Lakoff (1967). See the discussion of Lakoff's book by Touratier (1969).

2. Cf. Bortolussi (2006) for a more general history of generative grammar applied to ancient languages. See also Quetglas (1985/2006) for an excellent review of some relevant generative approaches to Latin linguistics. 
called "Principles and Parameters" framework, we get to The Minimalist Program (Chomsky 1995). In the last decades, generative linguistics has further evolved and differentiated in a wide range of orientations (e.g., see Chomsky, Gallego \& Ott 2017).

Generative grammar, by its nature, is constantly evolving: the aim of this school of thought is not the achievement of definitive truths, since every theoretical elaboration is considered as temporary. Although the continuous changes in the theoretical framework have somehow limited the success of generative grammar, two general assumptions on the nature of human language and the structure of scientific theories have remained unchanged throughout its whole history. We have to keep these assumptions in mind, in order to clearly understand the nature of this research and in order to avoid requiring from it something different from its nature.

Firstly, generative grammar assumes the nature of language as a very complex phenomenon. Therefore, the generative approach rejects all opinions reducing grammar to something banal, scholastic or prescriptive. Starting from the famous controversy of Chomsky against Skinner's behaviorism (Chomsky 1959), generative linguists have always believed that language should not be reduced to a behavioral system imposed by the environment or by the education. The linguistic research should not only reach a descriptive adequacy, but also an explicative adequacy, and this is only possible within a more general theoretical framework, i.e., a general theory of language whose main focus is the study of so-called "Universal Grammar". As a matter of fact, the existence of a Universal Grammar, from which particular grammars of the single languages can arise, is postulated for two reasons. Firstly, it states that the grammar of each language does not have an indefinite variability, but is subject to a series of universal principles. Secondly, it explains the naturalness and simplicity of language acquisition by children, even without a particular teaching, only on the basis of exposure to a flow of linguistic data from the input/environment.

This conception of language is strictly bound to the second essential postulate of generative grammar, i.e. the conception of science as a continuous refinement of theories, considered as approximations to an ultimate reality, which we will never be able to own in a definite form. Any theory should have the characteristic of being capable to be confirmed or falsified by the observation of data, and so no theory can be proved to be true at all. Therefore, the scientific progress not only consists on the accumulation of new observations of facts, but mostly on the subsequent theoretical hypotheses, increasingly refined and general. It is the same method currently used in natural sciences, which has been object of reflection by the epistemologist Karl Popper (1935). In this hypothetical-deductive conception of scientific research, "grammar" is considered as a theory of language, an abstract mechanism able to explain the particular characteristics of human language.

It follows that, by its nature, generative grammar is characterized by a formal approach. The technical term "to generate", drawn from mathematics, means "to enumerate explicitly", in order to formally describe infinite sets like human languages by means of a finite set of primitive elements and formal operations. Therefore, the leading characteristic of generative grammar is the use of formaliza- 
tion. From origins to today, the typical generative style of syntactic investigation has often been based on phrase structure and derivations, and the syntactic tree has often been the typical formal tool used with the purpose of providing an explicit structural description for any sentence.

According to what has been said so far, we can affirm the existence of a unitary "Chomskyan program", which does not have to be identified with a single thesis supported by this or that single scholar, but that forms a unitary style of research, which is applicable to the study of language in general or of specific languages. ${ }^{3}$

As is often the case for every research method in human sciences, this view is not acknowledged by all linguists, particularly by many of those who deal with ancient languages. We can find some scholars, whose aim is the elaboration of theories intended as perfect and not falsifiable systems, according to a certain reading of the Saussurean structuralism. We can also find many other scholars, who entirely deny the possibility of building general abstract theories, confining their activity to the collection and classification of data in always partial and changeable systems, according to another reading of the same structuralist tradition. This is why, as we will see, generative approaches have always been a minority in the field of Latin linguistics, but they have nonetheless provided useful contributions towards a more systematic, explanatory, and accurate analysis of the Latin language.

Thanks to the improvements accomplished in all the fields by generative grammar in the last years (see below), it is now possible to display the entire structure of Latin grammar in a unitary generative framework (Oniga 2004/2007; 2014). The formal description of many seemingly odd features of Latin grammar using a small number of simple and universal principles has also proved to be useful for the teaching of the language (Oniga, Iovino \& Giusti 2011).

\section{The transformational origins}

The first generative approaches to Latin syntax adopted Chomsky's $(1957,1965)$ transformational perspective. Although in these works Chomsky himself did not deal with classical languages, from the late 1960s to the early 1980s a widespread belief among classicists was that this research perspective could have useful applications to Latin. ${ }^{4}$ These studies are characterized by the central role played by the concept of "transformation". At first, we have a deep syntactic structure produced by phrase structure rules, necessary for the semantic interpretation, which is then modified by a certain number of transformations, which may add, move or remove elements, eventually reaching the form of the surface structure of the sentence.

3. See Uriagereka (1998), Haegeman (2006), Honda \& O’Neil (2007), and Larson (2010), for some pedagogical introductions to "thinking syntactically" from a generative perspective. Readers who are interested in learning about formal approaches to syntax but are not (quite) familiar with the Chomskian perspective are invited to consult these handbooks. Our recommendation is to do it in an order inverse to the chronological one: cf. the basic introductions by Larson (2010) and Honda \& O'Neil (2007), the intermediate one by Haegeman (2006), and the "advanced" introduction to minimalist syntax by Uriagereka (1998).

4. For example, see the remark by Guiraud (1972) and the review by Maraldi (1975). 
The already mentioned work by Lakoff (1968) is the most complete analysis of Latin subordination in this framework, following the model that was previously elaborated by generative linguists for the description of English.

Two other linguistic dissertations followed the one by Lakoff, but were not published: Binkert (1970) tried to provide an explanation of the Latin cases alongside prepositional constructs, with the hypothesis of the existence of abstract prepositions in deep structure, similarly to Lakoff's use of abstract verbs, while Conlin (1973) put forward new hypotheses on the controversial concept of transitivity.

The characteristics of deep structure, in use at that time, were also discussed by Kelly (1968), with reference to the structure of the noun phrase, and by Keiler (1970), with reference to the structure of the verb phrase. Around the middle of the 70s, we can find many other attempts that use the transformational approach to deal with some particular problems of Latin syntax, such as the semantics of cases (Calboli 1975; later also Taraba 1985), the comparative attraction (Giannecchini 1975), the ablative absolute (Castelli 1976), the reflexive pronouns (Milner 1978), and the infinitive structure (Calboli 1980; Pillinger 1980; Goggin 1983), i.a. In this latter sector, the "raising" theory was firstly formulated (Pepicello 1977; Bolkestein 1979), a transformation that moves a noun phrase from subject position in a complement clause into either subject or object position in the matrix clause, which still remains as a valid hypothesis.

\section{Principles and Parameters I: Government and Binding}

By the end of the 70s there was a crisis moment for the generative theory, with the transition to a new theoretical paradigm often referred to as "Government and Binding" (GB; see Chomsky 1981), which is the first version of the "Principles and Parameters" approach that was dominant in the 80s. GB was a modular theory which divided grammar into a number of distinct subcomponents with a single transformational rule "Move alpha", which in principle allowed any element to move anywhere at any point. The resulting overgeneration was handled by postulating various modules (e.g., Theta-theory, Case theory, etc.), which filtered out the undesired structures. Four levels of representation were posited where conditions of Universal Grammar applied, filtering out the illicit structures: D-Structure (DS), S-Structure (SS), Logical Form (LF), and Phonological Form (PF). The central grammatical relation was Government, a powerful grammar-internal relation that crucially held in a number of otherwise distinct modules.

This new theoretical framework gave an appearance of obsolescence to many previous transformational approaches to Latin syntax, deemed as innovative only a few years before. In addition, there was a spread of distrust towards generative grammar, progressively discredited and marginalized within the field of Latin linguistics, which had begun to organize a series of biennial international colloquia. For example, Bortolussi (2006: 57) remembers what Harm Pinkster wrote in his introduction to the proceedings of the colloquium he edited: "Transformational Generative Grammar, in its development over the years, has been the most influen- 
tial of all in Latin linguistics (which, however, is not to say that it has also contributed most to new insights into Latin)" (Pinkster 1983: XII: our italics). Two years later, Echarte Cossío (1985) reached a similar conclusion in her "meditations": she clearly set herself against generative grammar in favor of functional linguistics, expressing what would become the orthodoxy of Latin linguistics for many years. Gualtiero Calboli himself, who had followed generative grammar during the seventies, gradually abandoned it in the subsequent decades.

Therefore, generative research on Latin syntax continued in an unfavorable context. The few linguistic dissertations, such as those by Ostafin (1986), Bortolussi (1987), and Maurel (1989), were not published. The focus was almost exclusively put on the new syntactic phenomena examined by Chomsky (1981), i.e., government and binding. Latin was rightly recognized as a language that is particularly suitable for investigations on binding, because it clearly distinguishes the distribution of the reflexive pronoun from that of the free pronoun, and has long anaphors. Very thorough works in this field were carried out by Bertocchi and Casadio (1980; 1983), Bertocchi (1986), and Benedicto (1991). Furthermore, other types of pronouns, i.e. possessives, and particularly the abstract pronoun referred to as "null subject" (pro), were examined by Bertocchi (1985), Maraldi (1985), and Bertocchi and Maraldi (1990). As for the government theory, the contributions on accusative case by Bortolussi $(1988 ; 1991)$, and the ones on syntactic ambiguity by Bortolussi (1998), should also be remembered. Ros's (2001) contribution deals with binding theory (although, by that time, it was not at the center of Chomsky's grammatical thinking), and even more significantly suggests a return to the so-called "valency theory", i.e., to a pre-generative structuralist framework.

\section{Principles and Parameters II: The minimalist program. Other generative approaches}

An important impulse to generative approaches to Latin syntax was given after the rise of the new "minimalist" program put forward by Chomsky (1995). The research carried out in the "Principles and Parameters" framework aimed at studying linguistic variation, not only from a synchronic point of view but also from a diachronic one. On this basis, generative grammar faced some previous unresolved issues with renewed impetus. For example, see Miller (2000) for a derivational analysis of gerund and gerundive and Gianollo (2016) for a formal proposal of the syntax of negation and negative indefinites. The typological comparison between Latin and English within the theory of Principles and Parameters also gave origin to a new comparative syntax (e.g., see Haegeman 1997, i.a.), which encouraged the collaboration between scholars of Latin and other languages: e.g., new contributions have been produced on the analysis of infinitive sentences (Cecchetto \& Oniga 2002; 2004), on verbal ellipsis (Cecchetto \& Oniga 2104; 2016), and on the structure of noun phrase (Gianollo 2007; Giusti \& Oniga 2006, 2007; Iovino 2012).

Similarly, the collection of papers edited by Katalin É. Kiss (2005) succeeded in demonstrating that the concept of Universal Grammar could be useful in the 
restoration of the ancient languages' grammar, filling the documentary gaps with conceivable hypotheses, based on linguistic universals. The study of languages attested only by a closed corpus was not an obstacle for generative linguistics any more, but became a new and rising research field (Bortolussi 2009; Giusti \& Oniga to appear, i.a.).

Importantly, the identification of variable parameters next to universal principles allowed the researchers to deal with crucial issues for Latin linguistics, such as the diversity between archaic, classical and post-classical Latin, and the transition from Latin to Romance languages too. For example, concerning the evolution from Latin to Romance, two generative monographs have prevailed as the more complete and elaborated essays on the field, largely appreciated by non-generativists as well: Salvi (2004) and Ledgeway (2012).

Furthermore, the investigation of phenomena related to the periphery of the sentence enabled generative grammar to face the problem of the pragmatic functions, whose absence had been an evident disadvantage of generative approaches to Latin syntax compared to functionalist ones. Thereby, the longdating puzzle of word order, essential in Latin, which had been object of reflection in classical philology even before the birth of linguistics, could finally get new answers. Some important monographs spread new light on the field. Polo (2004) offered an extended comparison among Latin, Italian, and Slovene, combining statistical considerations with a careful evaluation of the informational structure of the sentence. Even more clearly, Devine and Stephens (2006) succeeded to reduce the intricate surface patterns of Latin word order to a simple and universal system of syntactic structures, which allows every phrase to host the constituents of pragmatic and semantic meaning. More recently, two monographs on word order in Latin have also appeared (see Danckaert 2012; 2017), where it is shown that a generative approach to this topic is compatible with a meticulous use of quantitative, corpus-based methods. Finally, it is also important to point out that there are generative linguists who have recently argued that movement in Latin does not take place in syntax but in the phonological component of the grammar, following the mapping from syntactic to prosodic structure (see Agbayani \& Golston 2016).

As for generative approaches to the syntax of argument structure (see Mateu 2014, i.a.), the recent monograph by Acedo-Matellán (2016) provides a very detailed formal account of the Talmyan typological classification of Latin within the set of so-called "satellite-framed languages" (see also Acedo-Matellán \& Mateu $2013 ; 2016)$. Another area of argument structure that has shown renewed interest in generative approaches to Latin is the syntax of deponent verbs (see Migliori 2016; Pinzin 2017, i.a.), psychological verbs (Cavallo 2014), and change of state verbs with -sc- suffix (Mateu 2017), i.a.

Last but not least, it is also important to mention that there are interesting non-Chomskian/non-transformational generative approaches to Latin syntax. For example, Vincent (2000) has argued for the validity of combining two non-derivational generative theories (Optimality Theory (OT) and Lexical Functional Grammar (LFG)) when dealing with the topic of null arguments in Latin and 
Romance. See also Haug (2016), Haug \& Nikitina (2012, 2016), and Jøhndal (2012) for some LFG-based approaches to other syntactic phenomena of Latin.

\section{The contributions in this volume}

The contributors of the present volume of Catalan Journal of Linguistics deal with important topics of Latin syntax. Acedo-Matellán's paper addresses a thorny issue of Latin argument structure: namely, those dative arguments that typically appear with some prefixed verbs. By adopting a syntactic approach to argument structure, he puts forward the hypothesis that these datives, which are interpreted as the Ground with respect to spatial preverbs (e.g. flumini incidere 'to fall into the river'), are best analyzed as applied arguments referencing an entity that possesses a null nominal sitting in a vP-internal prepositional phrase headed by the preverb (before it attaches to the verb). Two interesting consequences of this proposal are explored: (i) unprefixed verbs expressing change of location by themselves (e.g., venire or ire) are also expected to admit a dative identifying the goal of motion and (ii) unprefixed verbs of manner of motion (e.g., currere), which do not encode a resulting location, are prevented from taking these dative arguments.

Gianollo's paper deals with the conditions of use of negative particles such as neque / nec 'and not, neither, not even' and ne...quidem 'neither, not even', which are shown to present interesting phenomena at the syntax-semantics interface. These particles can express sentential negation while at the same time narrowly focusing on some constituent of the clause. They are shown to be multifunctional elements that can express various types of focus (additive or scalar) and, in the case of neque / nec, also have a coordinative and a discourse-structuring function. After providing an introduction to the Classical Latin system of negation and focus, the author analyzes ne... quidem and concentrates on the syntax of focus-sensitive negation. She then deals with the more complex case of neque / nec and uses semantic-pragmatic criteria to account for their various interpretations. A syntactic analysis is also proposed, highlighting the parallelism with ne...quidem. Finally, the diachronic implications of the analysis provided for Classical Latin are discussed.

Devine \& Stephens'paper offers an outline of a syntax-semantics interface for broad scope focus sentences in Latin which conforms with the facts of Latin syntax and uses independently available semantic mechanisms. As pointed out by the authors, the problem of how to interpret the arguments in their various syntactic positions can be dealt with in the context of an explicit syntactic theory as to what those positions are and, assuming a derivation, how and, particularly, why the arguments got there in the first place. The compositional system proposed in this paper is shown to be suitable for topicalized (and quite possibly scrambled) arguments; so it actually accounts for much of what has been perceived as free argument order in Latin. Importantly, the authors show that Latin does not have free word order in all sentences: sentences with broad scope focus have a regular default fixed order.

The topic of the rest of the papers is also word order, which indeed has a privileged status in many handbooks of Latin syntax. Bortolussi's paper deals with the cartography of the so-called "Left Periphery" in Latin and provides an overview 
of the different types of topic phrases in Latin. In particular, he claims that in Dislocations, which include Hanging Topics and Clitic Left Dislocations, the DP is base generated in a Left Periphery position, whereas in Topicalizations the DP has moved from an internal position up to a Left Periphery one. He also addresses the so-called "proleptic accusative" constructions, which are regarded as an alternative way of topicalizing the subjects of some subordinate clauses. The main conclusion to be drawn from his paper is that the cartography of Latin left periphery is not very different from the one to be found in languages with fixed word order.

Danckaert's paper deals with the issue of subject placement (VP-internal and $\mathrm{T}($ ense)P-internal) in Classical and Late Latin. The author addresses the important question as to how VP-internal and TP-internal subject XPs can unambiguously be identified as such and provides corpus evidence to show that one needs to distinguish an earlier grammar ('Grammar A', whose heyday is the period from ca. 200 $\mathrm{BC}$ until $200 \mathrm{AD}$ ), where there was no rule of A-movement displacing subjects to the TP-layer, and a later grammar ('Grammar B', which is on the rise from ca. 50-100 AD, and fully productive from ca. $200 \mathrm{AD}$ onwards) where subjects optionally move to the inflectional layer. It is shown that it is only in the Late Latin period that TP-internal subjects fully establish themselves as a grammatical option. Finally, it is speculated that the shift to a head-initial T-node may have contributed to this development.

Finally, Ledgeway's paper offers a systematic study of the word order patterns of the Itinerarium Egeriae, one of the best known texts of the Late Latin period, to show how they differ from those of Classical Latin and modern standard Romance languages. Despite enjoying an apparently greater degree of freedom than the latter, though less than that of the Classical language, the Late Latin word order of the Itinerarium Egeriae is shown nonetheless to be constrained by a number of clearly definable structural principles which ultimately characterize it as a V2 language. The article therefore offers very valuable original evidence for the growing consensus among linguists that, typologically, Late Latin and Medieval Romance displayed a high degree of structural cohesion in presenting a uniform V2 rule.

Each paper has been reviewed by two anonymous reviewers and we are very grateful to them for their efforts and help. We hope that readers will find our selected papers interesting and inspiring.

\section{References}

Acedo-Matellán, Víctor. 2016. The Morphosyntax of Transitions. A Case Study in Latin and Other Languages. Oxford \& New York: Oxford University Press. $<$ https://doi.org/10.1093/acprof:oso/9780198733287.001.0001>

Acedo-Matellán, Víctor \& Jaume Mateu. 2013. Satellite-framed Latin vs. verb-framed Romance: A syntactic approach. Probus. International Journal of Latin and Romance Linguistics 25: 227-265. $<$ https://doi.org/10.1515/probus-2013-0008>

Acedo-Matellán, Víctor \& Jaume Mateu. 2016. Argument structure and satellite-framedness in Latin: Evidence from unselected object constructions. In Poccetti, 
Paolo (ed.). Latinitatis rationes. Descriptive and Historical Accounts for the Latin Language, 149-169. Berlin: De Gruyter. $<$ https://doi.org/10.1515/9783110431896-012>

Agbayani, Brian \& Golston, Chris. 2016. Phonological Constituents and their Movement in Latin. Phonology 33: 1-42.

$<$ https://doi.org/10.1017/S0952675716000026>

Benedicto, Elena. 1991. Latin long-distance anaphora. In Koster, Jan \& Reuland, Eric (eds.). Long-distance anaphora, 171-184. Cambridge \& New York: Cambridge University Press.

Bertocchi, Alessandra. 1985. Subject ellipsis and case agreement. In Touratier, Christian (ed.). Syntaxe et latin, 25-37. Aix-en-Provence: Publications de l'Université de Provence.

Bertocchi, Alessandra. 1986. Anaphor and tense in Latin. Papers on Grammar 2: 63-86.

Bertocchi, Alessandra \& Casadio, Claudia. 1980. Conditions on anaphora: an analysis of reflexive in Latin. Papers on Grammar 1: 1-46.

Bertocchi, Alessandra \& Casadio, Claudia. 1983. Anaphoric relations, pronouns and Latin complementation. In Pinkster, Harm (ed.). Latin Linguistics and Linguistic Theory, 27-39. Amsterdam: John Benjamins.

Bertocchi, Alessandra \& Maraldi, Mirka. 1990. Nominalization and possessives in Latin. Papers on Grammar 3: 69-127.

Binkert, Peter Joseph. 1970. Case and Prepositional Construction in a Transformational Grammar of Classical Latin. PhD dissertation, University of Michigan.

Bolkestein, A. Machtelt. 1979. Subject-to-object raising in Latin? Lingua 48: 15-34. $<$ https://doi.org/10.1016/0024-3841(79)90089-5>

Bortolussi, Bernard. 1987. Considérations sur l'accusatif latin. Thèse d'État, Paris VII.

Bortolussi, Bernard. 1988. L'accusatif d'objet interne. In Weber, Heinrich \& Zuber, Ryszard (eds.) Linguistik Parisette (Akten des 22 Linguistischen Kolloquiums, Paris 1987), 73-81. Tübingen: Niemeyer.

Bortolussi, Bernard. 1991. Critères d'identification de l'objet en latin. Stemma 1: 11-21.

Bortolussi, Bernard. 1998. Facite uentum ut gaudeam. Quelques phénomènes d'ambiguïté syntaxique. In García-Hernandez, Benjamín (ed.). Estudios de Lingüística Latina (Actas del IX Coloquio Internacional de Lingüística Latina: Universidad Autónoma de Madrid, 1997), 203-216. Madrid: Ediciones Clásicas.

Bortolussi, Bernard. 2006. La grammaire générative et les langues anciennes. Lalies 26: 57-102.

Bortolussi, Bernard. 2009. La grammaire générative et le latin: exemples construits et utilisation des corpus. Mémoires de la Société de Linguistique de Paris 16: 99-119.

Calboli, Gualtiero. 1975. La linguistica moderna e il latino. I casi. Bologna: Pàtron.

Calboli, Gualtiero. 1980. Bemerkungen zum Akk.c.Inf. und zu verwandten Konstruktionen in Lateinischen. Papers on Grammar 1: 189-208.

Castelli Anna Luisa. 1976. Il tipo praesente nobis. Studi Italiani di Linguistica Teorica e Applicata 5: 57-78.

Cavallo, Guido. 2014. The Latin psych verbs of the é-class: (de)transitivization and syntactic alignement. $\mathrm{PhD}$ dissertation, Università degli Studi di Padova. Downloadable at $<$ http://paduaresearch.cab.unipd.it/6880/>. 
Cecchetto, Carlo \& Oniga, Renato. 2002. Consequences of the analysis of Latin infinitival clauses for the theory of case and control. Lingue e Linguaggio 1: 151-189. $<$ https://doi.org/10.1418/7560>

Cecchetto, Carlo \& Oniga, Renato. 2004. A Challenge to Null Case Theory. Linguistic Inquiry 35: 141-149.

$<$ https://doi.org/10.1162/002438904322793374>

Cecchetto, Carlo \& Oniga, Renato. 2014. Constituency as a Language Universal. The Case of Latin. Lingue antiche e moderne 3: 5-35.

Cecchetto, Carlo \& Oniga, Renato. 2016. Considerazioni sul fenomeno dell'ellissi verbale. In Poccetti, Paolo (ed.). Latinitatis rationes. Descriptive and historical accounts for the Latin language, 189-199. Berlin: De Gruyter. $<$ https://doi.org/10.1515/9783110431896-014>

Chomsky, Noam. 1957. Syntactic structures. The Hague: Mouton.

Chomsky, Noam. 1959. A Review of B. F. Skinner's Verbal Behavior. Language 35: 26-58.

Chomsky, Noam. 1965. Aspects of the theory of syntax, Cambridge, MA: MIT Press.

Chomsky, Noam. 1973. Conditions on transformations. In Anderson, Stephen \& Kiparsky, Paul (eds). A Festschrift for Morris Halle, 232-286. New York, Holt.

Chomsky, Noam. 1981. Lectures on Government and Binding. Dordrecht: Foris.

Chomsky, Noam. 1995. The Minimalist Program. Cambridge, MA: MIT Press.

Chomsky, Noam, Gallego, Ángel \& Ott, Dennis (2017). Generative Grammar and the Faculty of Language: Insights, Questions, and Challenges. Manuscript, MIT, Universitat Autònoma de Barcelona, and University of Ottawa. To appear in Catalan Journal of Linguistics. Downloadable at $<$ http://ling.auf.net/lingbuzz/003507>.

Conlin, Victoria C. 1973. A localist theory of Latin case. PhD dissertation, University of Toronto.

Danckaert, Lieven. 2012. Latin Embedded Clauses. The Left Periphery. Amsterdam \& Philadelphia: John Benjamins. $<$ https://doi.org/10.1075/la.184>

Danckaert, Lieven. 2017. The Development of Latin Clause Structure. A Study of the Extended Verb Phrase. Oxford \& New York: Oxford University Press. $<$ https://doi.org/10.1093/oso/9780198759522.001.0001>

Devine, Andrew M. \& Stephens, Laurence D. 2006. Latin word order. Structured meaning and information. Oxford \& New York: Oxford University Press. $<$ https://doi.org/10.1017/S0009840X10000430>

Echarte Cossío, María José. 1985. Meditaciones sobre dos métodos para el análisis de la lengua latina. Generativismo y Funcionalismo. Estudios Clásicos: 27/89: 157-169.

Kiss, Katalin É. (ed.). 2005. Universal Grammar in the Reconstruction of Ancient Languages. Berlin: De Gruyter. $<$ https://doi.org/10.1515/9783110902228>

Giannecchini, Gianni. 1975. L'attrazione del comparativo in latino. Uno studio trasformazionale. Annali della Facoltà di Lettere dell'Università di Perugia 13: 309-337.

Gianollo, Chiara. 2007. The internal syntax of the Nominal Phrase in Latin. A diachronic study. In Purnelle, Gérald \& Denooz, Joseph (eds.). Ordre et cohérence en latin, 65-80. Liège: Droz. 
Gianollo, Chiara. 2016. The Latin system of negation at the syntax-semantics interface. Rivista di Grammatica Generativa 38: 115-135.

Giusti, Giuliana \& Oniga, Renato. 2006. La struttura del sintagma nominale latino. In Oniga, Renato \& Zennaro, Luigi (eds.). Atti della Giornata di Linguistica Latina, 71-100. Venezia: Cafoscarina.

Giusti, Giuliana \& Oniga, Renato. 2007. Core and periphery in the Latin noun phrase. In Purnelle, Gérald \& Denooz, Joseph (eds.). Ordre et cohérence en latin, 81-95. Liège: Droz.

Giusti, Giuliana \& Oniga, Renato. To appear. Il latino come corpus linguistico per una teoria della sintassi nominale: risultati e prospettive. In De la Villa, Jesús \& Pompei, Anna (eds.). Classical Languages and Linguistics. Madrid: Universidad Autónoma de Madrid.

Goggin, John. 1983. Linking chains: control and case-marking in Latin infinitives. Texas Linguistic Forum 22: 61-86.

Guiraud, Charles. 1972. Linguistique latine, structuralisme et grammaire générative. L'information littéraire 24: 171-175.

Haegeman, Liliane (ed.). 1997. The New Comparative Syntax. London: Longman.

Haegeman, Liliane. 2006. Thinking Syntactically. A Guide to Argumentation and Analysis. Malden \& Oxford: Blackwell.

Haug, Dag Trygve Truslew. 2016. Backward control in Ancient Greek and Latin participial adjuncts. Natural language and linguistic theory. 35(1): 99-159. $<$ https://doi.org/10.1007/s11049-016-9339-7>

Haug, Dag Trygve Truslew \& Nikitina, Tatiana. 2012. The many cases of non-finite subjects: the challenge of "dominant" participles in Latin. In Butt, Miriam \& King, Tracy H. (eds.). Proceedings of the LFG 12 Conference, 292-311. Stanford: CSLI Publications.

Haug, Dag Trygve Truslew \& Nikitina, Tatiana. 2016. Syntactic nominalization in Latin: A case of non-canonical subject agreement. Transactions of the Philological Society. 114(1): 25- 50. $<$ https://doi.org/10.1111/1467-968X.12061>

Honda, Maya \& O’Neil, Wayne. 2007. Thinking Linguistically. A Scientific Approach to Language. Malden \& Oxford: Blackwell.

Iovino, Rossella. 2012. La sintassi dei modificatori nominali in latino. München: Lincom Europa.

Keiler, Allan R. 1970. Some Problems of Latin Deep Structure. Classical Journal 65: 208-213.

Kelly David H. 1968. Transformations in the Latin nominal phrase. Classical Philology 63: 46-52. $<$ https://doi.org/10.1086/365317>

Jøhndal, Marius L. 2012. Non-finiteness in Latin. PhD dissertation, University of Cambridge. Downloadable at <http://folk.uio.no/mariuslj/johndal-2012-phddissertation.pdf $>$.

Lakoff, Robin Tolmach. 1967. Studies in the Transformational Grammar of Latin. The Complement System. PhD dissertation, Harvard University.

Lakoff, Robin Tolmach. 1968. Abstract Syntax and Latin Complementation. Cambridge, MA: MIT Press.

Larson, Richard. 2010. Grammar as Science. Cambridge, MA: MIT Press. 
Ledgeway, Adam. 2012. From Latin to Romance: Morphosyntactic Typology and Change. Oxford: Oxford University Press.

$<$ https://doi.org/10.1093/acprof:oso/9780199584376.001.0001>

Maraldi, Mirka. 1975. Recenti studi di grammatica trasformazionale e loro possibile applicazione al latino. Giornale Italiano di Filologia 27: 227-247.

Maraldi, Mirka. 1985. Null subjects: some implications for Latin syntax. In Touratier, Christian (ed.). Syntaxe et latin, 41-53. Aix-en-Provence: Publications de l'Université de Provence.

Mateu, Jaume. 2014. Argument structure. In Carnie, Andrew et al. (eds.). The Routledge Handbook of Syntax, 24-41. New York: Routledge.

Mateu, Jaume. 2017. State and Change of State in Latin. A View from the LexiconSyntax Interface. In Fernández-Soriano, Olga et al. (eds.). Boundaries, Phases and Interfaces. Case Studies in Honor of Violeta Demonte, 344-366. Amsterdam \& Philadelphia: John Benjamins. $<$ https://doi.org/10.1075/la.239.16mat>

Maurel, Jean- Pierre. 1989. Le syntagme nominal en latin. Les emplois du génitif chez Plaute et Térence. Thèse d'Etat, Strasbourg II.

Migliori, Laura. 2016. Argument structure, alignment and auxiliaries between Latin and Romance. $\mathrm{PhD}$ dissertation. Leiden University. Downloadable at $<\mathrm{https}$ ://ope naccess.leidenuniv.n1/handle/1887/40052>.

Milner, Jean-Claude. 1978. Le système du réfléchi en latin. Langages 50 : 73-86.

Miller, D. Gary. 2000. Gerund and gerundive in Latin. Diachronica 17 (2): 293-349. $<$ https://doi.org/10.1075/dia.17.2.03mil >

Oniga, Renato. 2004. Il latino. Breve introduzione linguistica. 2nd edition revised in 2007. Milano: Franco Angeli.

Oniga, Renato. 2014. Latin: A Linguistic Introduction. Oxford: Oxford University Press.

Oniga, Renato, Iovino, Rossella \& Giusti, Giuliana (eds.). 2011. Formal Linguistics and the Teaching of Latin. Newcastle upon Tyne: Cambridge Scholars Publishing.

Ostafin, David Mark. 1986. Studies in Latin word order. A transformational approach. $\mathrm{PhD}$ dissertation, University of Connecticut, Storrs.

Pepicello William J. 1977. Raising in Latin. Lingua 42: 209-218. $<$ https://doi.org/10.1016/0024-3841(77)90028-6>

Pillinger, Owen Stephen. 1980. The Accusative and Infinitive in Latin: A Refractory Complement Structure. Journal of Linguistics 16: 55-83.

$<$ https://doi.org/10.1017/S0022226700006344>

Pinkster, Harm (ed.).1983. Latin Linguistics and Linguistic Theory. Amsterdam: Benjamins.

Pinzin, Francesco. 2017. Deposing deponency: Latin non-denominal deponents are not grammatically idiosyncratic verbs. Journal of Latin Linguistics 16: 11-42. $<$ https://doi.org/10.1515/joll-2017-0006>

Polo, Chiara. 2004. Word order between morphology and syntax. Padova: Unipress.

Popper, Karl. 1935. Logik der Forschung. Wien: Springer (Engl. transl. 1959. The Logic of Scientific Discovery. London \& New York: Hutchinson \& Co.).

Quetglas, Pere J. 1985. Elementos básicos de filología y lingüística latinas. Barcelona: Teide (2nd ed., 2006. Barcelona: Publicacions i Edicions de la Universitat de Barcelona). 
Ros, Hilke. 2001. Binding theory and valency grammar in Latin. Glotta 77: 244-261.

Salvi, Giampaolo. 2004. La formazione della struttura di frase romanza. Tübingen: Narr.

Taraba, Jan. 1985. Valeurs d'ensemble des cas et rôles sémantiques, avec application aux nominatifs et accusatifs latins. Graecolatina et Orientalia 27: 67-87.

Touratier, Christian.1969. Syntaxe latine et grammaire générative. Revue des Etudes Latines 47: 106-121.

Vincent, Nigel. 2000. Competition and Correspondence in Syntactic Change: Null Arguments in Latin and Romance. In Pintzuk, Susan et al. (eds.). Diachronic Syntax. Models and Mechanisms, 25-50. Oxford \& New York: Oxford University Press.

Uriagereka, Juan. 1998. Rhyme and Reason. An Introduction to Minimalist Syntax. Cambridge, MA: The MIT Press. 
